\title{
CSR Is a Management Practice to Improve Financial Performance of Banks: A Study on Banks of Dhaka City, Bangladesh
}

\author{
Farhanaz Luna ${ }^{1} \&$ Shadia Sharmin ${ }^{2}$ \\ ${ }^{1}$ School of Business, Fareast International University, Dhaka, Bangladesh \\ ${ }^{2}$ Department of Business Administration, University of South Asia, Dhaka, Bangladesh \\ Correspondence: Shadia Sharmin, Lecturer, Department of Business Administration, University of South Asia, \\ House-78, Road-14, Banani, Dhaka 1213, Bangladesh. E-mail: Shadiasharmain2013@gmail.com
}

\author{
Received: May 26, 2015 \\ Accepted: June 14, 2015 \\ Online Published: July 17, 2015 \\ doi:10.5430/ijba.v6n4p79 \\ URL: http://dx.doi.org/10.5430/ijba.v6n4p79
}

\begin{abstract}
CSR ensure a balance between economic and social goals of the efficient utilization of scare resources. CSR practice by banks not only improves their own status but also improve the society as a whole. CSR can also increase profitability of the banks and can promote respect for the banks in the marketplace. So, the role of banks is to ensure pursuing CSR practices to developed society. Banking sector can also be benefited economically by positive effect of CSR on the society as a whole specially on its client which bring higher sales.
\end{abstract}

Keywords: CSR, economic, society, banks, profitability

\section{Introduction}

CSR means Corporate Social Responsibility (CSR, also called corporate conscience, corporate citizenship or sustainable responsible business/ Responsible Business). It is a self regulatory by a business where business can ensure and monitor its active compliance with the spirit of law, ethical standard and international norms. In some of the cases CSR goes beyond compliance and engages in actions that beyond the interest of the firm and appears some social good. CSR encourage corporate body behave more rationally to environment and its stakeholder including customers, suppliers, investors, employees, social communities and others.

In 1953, the concept of Corporate Social Responsibility was first mentioned in the publication "Social Responsibility of the Businessman" by William J. Bowen. But the term popular in the 1990s when a generic pharmaceutical company named German Betapharm, a generic pharmaceutical company decided to implement CSR. The halt of sale growth in1997 led company to the realization that in the generic drug market companies could not make differentiation in price or quality. This was lead up for the company to adopt CSR. It adds as an expression in company value and strategies. It is a strategic advantage for German Betapharm by using strategic and social commitment for families with chronically ill children.

The European Commission decided to launch a consultative paper on Corporate Social Responsibility with the title "Promoting a European Framework for Corporate Social Responsibility" in July 2001. This paper is promotion on how the European Union could promote Corporate Social Responsibility at both European and international Level. CSR practices are promoted to encourage ensuring credibility of CSR claims.

Bangladesh is third world developing country. The estimated population size is near 16 cores. The birth rate is high and the density of population is also very high. Based on the different report there are 1,101 people are living per Km. In case of Dhaka City the density of population rate is higher. The unplanned urbanization is reason for it. Most of the people are living in slum area of Dhaka City. The living standard of the people is very low, unhygienic and unsafe in Dhaka City. Being third world country it is not possible for our government to ensure all the standard of living. Here the corporate governances can play a vital role.

In Bangladesh no of group of companies are very limited in number. Whereas there are 56 banks are operating in Bangladesh. There are four state owned commercial banks such as Sonali bank Limited, Janata Bank Limited, Agrani Bank Limited, Rupali Bank Limited. And four specialized bank such as Bangladesh Krishi Bank, BASIC Bank, Bangladesh Development Bank which are establish for specific objectives basically for economic and social 
development of deprived people. Thirty Nine private commercial banks which are entitle by private owners. Private commercial banks are divided in two groups: Conventional PCBs and other is Islami Shariah based PCBs.

There are thirty one conventional PCBS are operating in Bangladesh. In these thirty one conventional banks nine are operating branches in abroad. All the conventional Commercial banks are perform their banking operation in conventional fashion i.e. interest based operation. And eight IslamiShariah bankare operating their banking activities according to IslamiShariah based principle i.e. profit-loss sharing (PLS) mode.

\section{Overview of Corporate Social Responsibility}

Corporate social responsibility means it is the responsibility of the corporate to do rational behavior to society. Society is the main sufferer of the corporate activities. If corporation behave rationally to society, society will exist and corporation can be developed. Through CSR corporation does not do any charity, it is compensation by the corporation to its stakeholder groups. In a word it can be said that corporate social responsibility means behave responsibly to society. CSR identifying its stakeholder groups needs and values in day to day decision-making process. These stakeholders are needed by the corporation for its operation perspective.

All though CSR is a concept whereby corporate decide voluntarily to contribute to a better society and a cleaner environment. Corporate social responsibility is a social investment of business activities. It is also connect with the sustainable development of the company's level. Over the last few decades there are large numbers of companies' worldwide stated promoting Corporate Social Responsibility strategy because the customers, the public and the investors expect them to act sustainable as well as responsible. In most of the cases Corporate Social Responsibility is a result of environmental, social and economic pressures. CSR is not only referring to the labor, human rights and social arrangement, it is more than that. It is a fight against climate change, sustainable management of natural resources and customer protection.

Today world is changing because of globalization. Now the whole world has become a global village. An inaccuracy occurs in any place of the world by any corporation is spread all over the world through media and internet. So, behaving responsibly is more important for any corporation. For example: the collapse down of Rana Plaza factory news is spread all over the world within in a few hours. The tragedy also exposes some companies inconsistencies with respect of Corporate Social Responsibility. Take the case of Wal-Mart, a one month after the crisis, a dozen of European firms (Like H\&M, Carrefour, Mark \& Spencer etc) refused to sign on the safety measure .Those companies agreed to have rigorous independent inspection of the factories they contact with Bangladesh and try to help them improvement of building.

In case of Rana Plaza case the world Media and Socialist is accused western buyer for their irresponsible behavior. They accused western buyer for their capitalism (Because they completely lead their activities to cost cutting and shortcut safety standard). They also claim that the short deadline of the order is one of the reason that force workers to go back to work in unsafe zone.

The fundamental element of CSR is that it brings benefits of active involvement in communities by companies. The business strategist Robert moment state in his article "The 7 Principle of Business Integrity" that 21st-century companies must prove themselves to customers to build long term, trusting relationship. They must also involve in the community to give back. This connection with community will make a close relationship of your company with local markets in which you operate.

\section{Objectives of the Study}

These are the following objectives of the study

- To get an idea about CSR practices among the banks

- To know that CSR is an expenditure or investment for the bank

- To know CSR increases the profit or not

- To know the impact of CSR in our society

\section{Literature Review}

For whatever reasons-if a company's choose to do right thing, its' bring good for their business in a long run. According to Sunny Misser, global and US leader of Pricewaterhouse- If a corporate sustainable practice of Corporate Social Responsibility within the next 18 to 24 months, its monitor practices and reporting will no longer discretionary or even provide a competitive advantage. "It will become a competitive necessity. The World Business Council for Sustainable Development (WBCSD) defines "CSR is the continuing commitment of business to contribute to 
sustainable economic development and improving living standard of workforce, their families and as well as local community. (WBCSD, 2001)

In a latest global CEO attitude survey, $79 \%$ of CEOs agreed that sustainable practice of CSR is vital to the profitability of their company. The corporate American acknowledged of Corporate Responsibility have been saying for years that good corporate behavior combined with sound business fundamental provide a sustainable long-term strategy for a corporation. According to Lynn S. Paine, head of the faculty interest group on ethics, law and leadership at Harvard Business School, the motive of becoming good corporate citizens are less noble for most of the executive. "Sure, there are some, who say, 'Gee, it's just better way to do business," she says. But the most business gain social conscience for risk management (after a crisis or a scandal -the rival are ready to catch for wrongdoing), reputation concern, external pressure for regulators and attracting high quality employees. Because now a day's unethical corporate behavior will lead to more regulation. The growth of social awareness in companies has significant development in the global commercial environment: the dramatic rise in importance of the brand. Simon Webley research director at the Institute of Business Ethics in London, says, "The company success is increasingly depend on public perception of its brand". The dramatic rise in importance of brand has significant development in the global commercial environment has paralleled growth of social awareness. According to Simon Webley research director at the institute of business. Corporate Social responsibility (CSR) has become a mainstream business activity (e.g. The Economist 2008). Most of the American and European companies are investing more resource in public goods and many companies are reducing negative externalities below levels required by law. Among the Fortune Global 250 firms, more than half firms are regular provide public statement discussing CSR, approximately 10 percent of S \& P 100 companies report in detail on CSR activities (Kotler and Lee2004a; Baskin and Gordon 2005). Approximately one third of the large U.S.A firms' voluntary external certifications for social and environmental standard and 11 percent of professional managed U.S.A. Investment was certified as socially responsible. It is estimated that U.S.A. and European markets have over 2 billion USD and 300 billion EURO in certified socially responsible assets (Social Investment Forum 2006). The CSR efforts is even inform to the potential employees by firms like IBM, General Motors or Microsoft. Corporate Social responsibility is high profile public issue now. An extensive global survey it was found that two-thirds of people reported that they would like companies to contribute to social goals beyond shareholder wealth. (Environics International 1999)

After providing literature review of CSR in different context, in this research we are righting to show how CSR practice by management can improve the financial performance of the banks in Dhaka City. Bangladesh is a third world developing country; Dhaka is the capital city of it. It is an over-crowded most populated city in the world, as part of developing country its literature rate is not that much high. Sometimes people are fighting of their basic needs. They have very little knowledge of ethical and responsible behavior of business. In spite of all these when the bank behaves responsibly still it has effect on people mind. This will create good brand image in society.

\section{Methodology}

The respondents will selected by using random sampling methods. We have selected twenty five banks in Dhaka City for the research. From these twenty five banks near about one hundred interviewees are interviewed personally and through e-mail. In these one hundred interviewees we included officer, executive, assistant manager, manager, assistant vice president, vice president of the banks.

A semi-structured open-end and close-end questionnaire has been developed. The questionnaire is short and analytical in nature. Data has been collected from secondary and primary sources and complied for quantitative analysis. For depth understanding of research qualitative methods is also used. Microsoft office excels and Likert scale methods have been used for analysis the quantitative data. The analysis results are presented in different charts and graph.

\section{Findings}

Likert scale: A method of ascribing quantitative value to qualitative data, to make it amenable to statistical analysis. A numerical value is assigned to each potential choice and a mean figure for all the responses is computed at the end of the evaluation or survey.

\begin{tabular}{ll} 
Strongly Agree & 1 \\
Agree & 2 \\
Neutral & 3 \\
Disagree & 4 \\
Strongly Disagree & 5 \\
\hline
\end{tabular}




\subsection{CSR Is a Resource Intensive and Costly Concept}

At present bankers disagree with the statement that CSR is a costly concept. In our research we have found that bankers think CSR is not a costly concept rather it is an investment for future profit of a business. Banks of Bangladesh are now trying to increase their budget on CSR. Central bank of Bangladesh is also very much concern about CSR practice by banks.

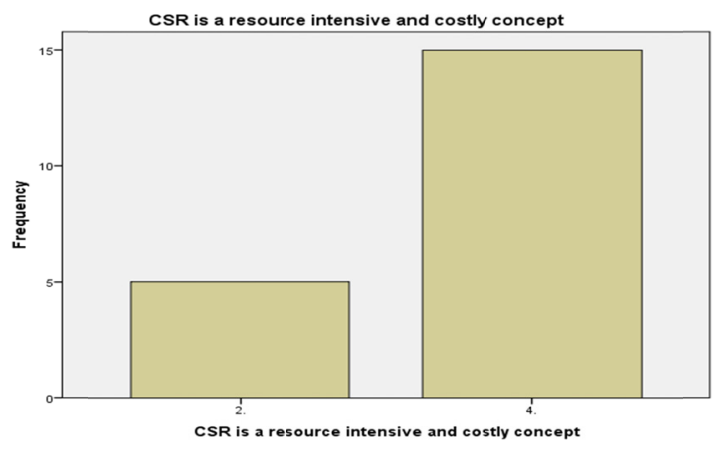

\subsection{CSR Needs to be Legislated to Ensure a Wide Uptake}

Legislation is important for setting standard of business and control the govern action of public and organization. Legislation is a law that has been place by the actions of governing body. Most of the bankers are agreed that CSR needs to be legislated to ensure a wide uptake.

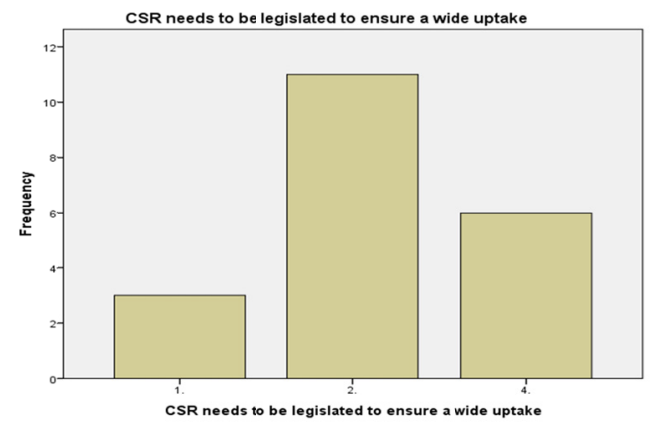

\subsection{A Responsible Company Is a Firm That Strictly Abides to Labor and Environmental Laws}

A responsible company is company which behaves responsibly to its stakeholder groups. Every company is responsible to society. Being a responsible company an ethical framework is must. In our research we have seen that our interviewees are strongly agreed with the statement that a responsible company should abide to labor and environmental laws.

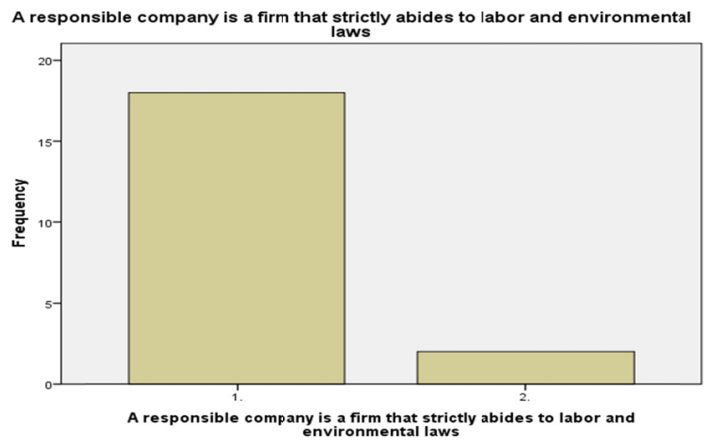




\subsection{CSR Is an Equivalent for Corporate Governance}

Corporate governance is the rules and regulation practice and process by which a company is directed. It is essential for balancing the interests of the many stakeholders in a company. Through the corporate governance company can manage its transparency. Transparency is the ways run a company on behalf of the shareholders by its manager. The respondents are strongly agreed with the statement that corporate social responsibility is equivalent to corporate governance.

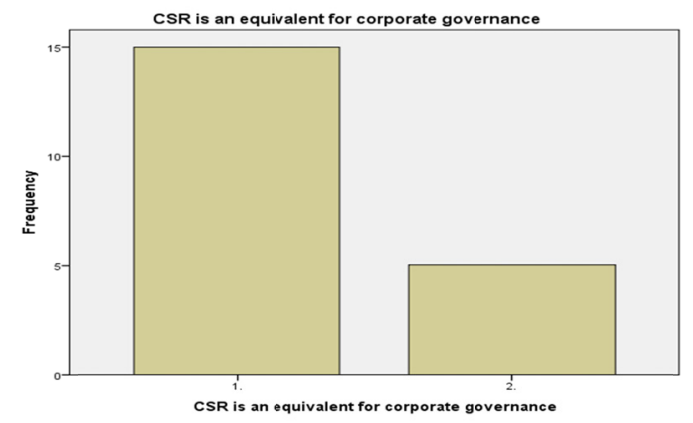

\subsection{CSR Is an Equivalent for Philanthropy (Humanity)}

Humanity is the characteristics that belong uniquely to human beings, such as kindness, mercy and sympathy. The respondents are agreed with the statement.

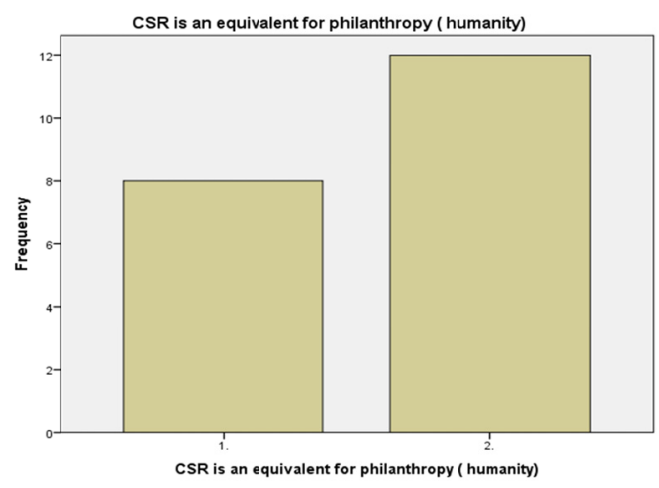

\subsection{CSR Includes Actions to Protect the Environment}

The environmental challenges the world faces today have the potential to significantly alter how society functions and require a coordinated global effort. Our respondents were strongly agreed with the statement.

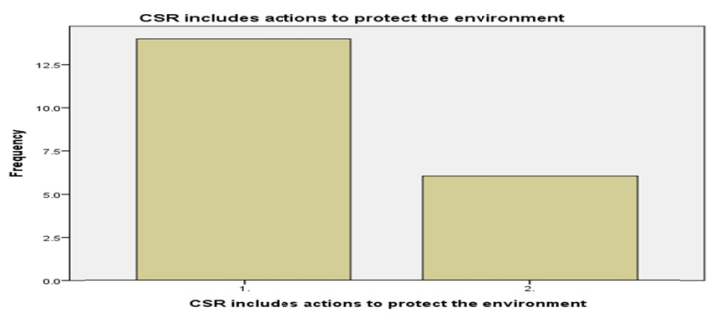




\subsection{CSR Encompasses a Set of Activities Companies Carry out Independently of Their Daily Business Operations}

As under the CSR program, companies usually operate their business in ethical and socially responsible manner. Our respondents were agreed with the statement.

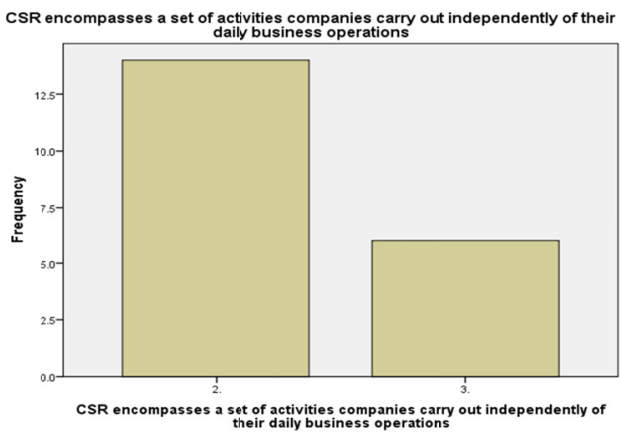

6.8 CSR Is Concept Which Is More Important for Companies Located in Developed than in Developing Countries

In the developed countries CSR is already an essential part of modern business. Many companies have admitted this way not only because of their own position in this matter, but because of social pressure. Our most of the respondents were agreed with the statement.

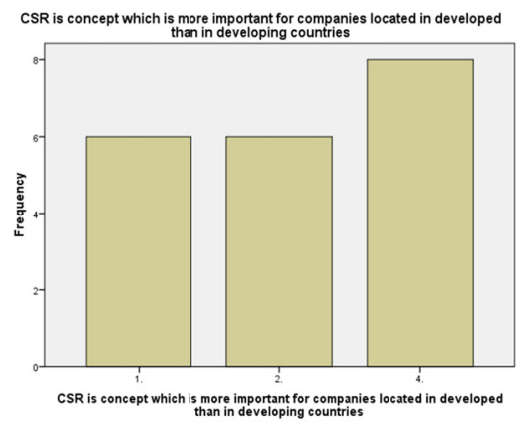

\subsection{CSR Is More Relevant for the Manufacturing Industries than for the Service Sector}

In service sector direct human interaction is needed. A small mistake can bring huge losses for the organization. CSR creates good will for business which is more important for service organization. On the other hand manufacturing firms also need do some social works for maximizing their profit. The respondents also disagree with the statement.

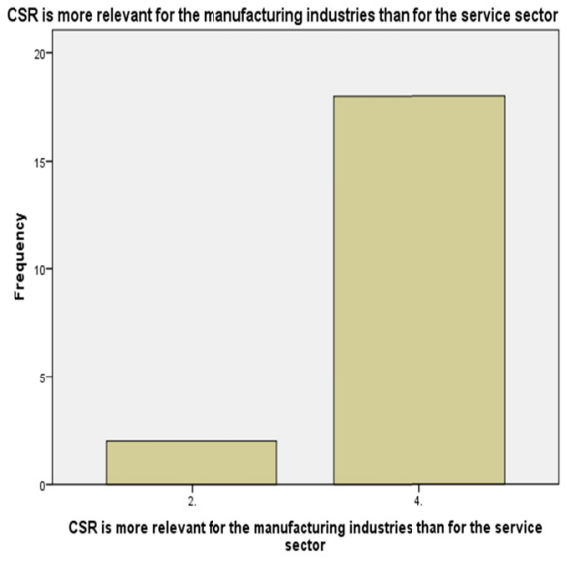




\subsection{CSR Is Primarily Motivated by Public Relations or Marketing Considerations}

By the doing CSR firm's public relation has become improved, increase good will in the market and create brand image for the organization. Our respondents agreed with the statement that CSR is primarily motivated by public relations or marketing considerations.

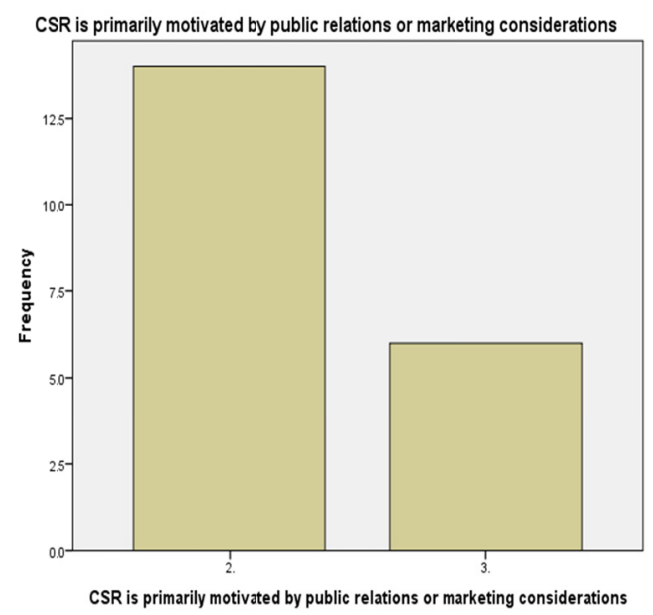

\subsection{CSR Can Lead to an Increase in Profits}

Most executives believe that CSR can improve profits. They understand that CSR can promote respect for their company in the marketplace which can result in higher sales, enhance employee loyalty and attract better personnel to the firm. Also, CSR activities focusing on sustainability issues may lower costs and improve efficiencies as well.

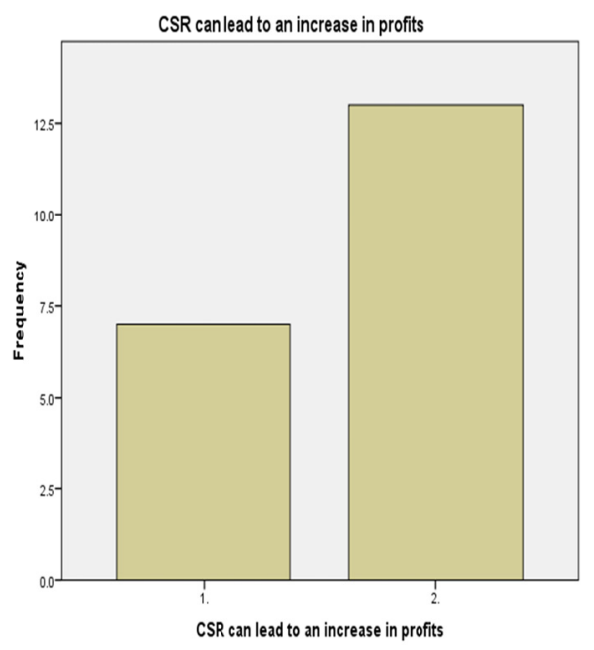

\section{Implication of the Study}

Here we have showed the effect of CSR of banks profit. 
Bank Asia

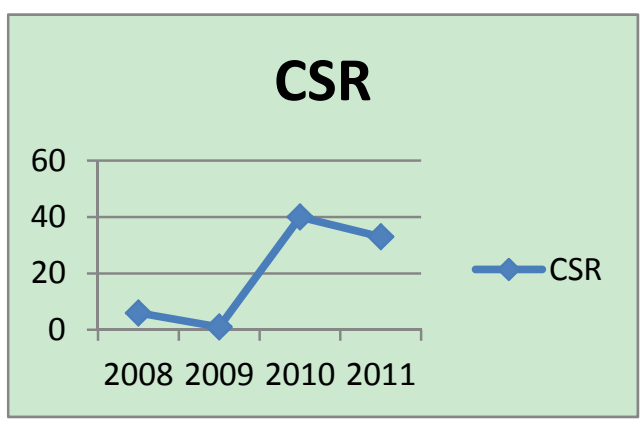

In million

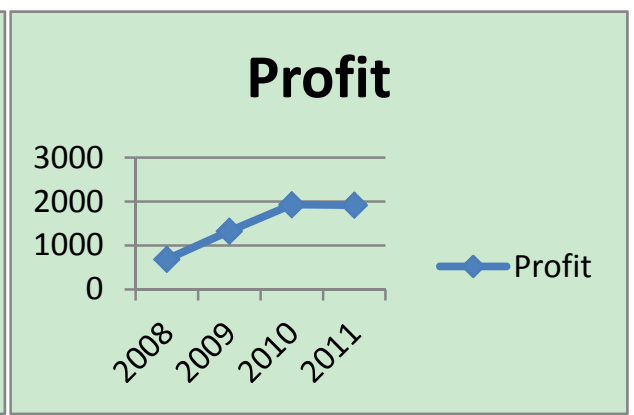

Here we can see that when CSR is rising in 2010 the profit was also jumped. Then in 2011 CSR amount fell as did the profit also. So, here we are seeing that profit has relationship with CSR.

EBL

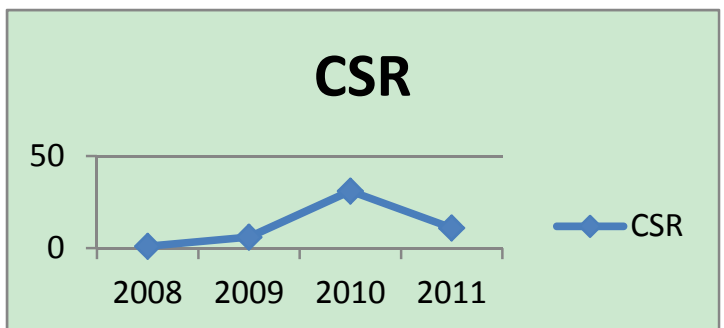

In million

\section{Profit}

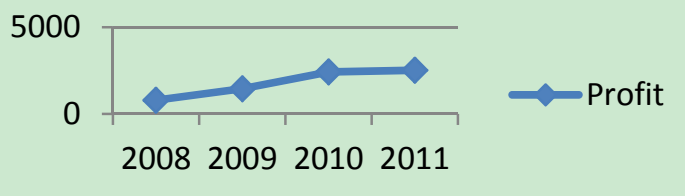

Here in terms of EBL when in 2008 there were no CSR activities by the bank so we can see that the profit was also lower. In 2010 CSR activities jumped as did the profit also. But in $2011 \mathrm{CSR}$ activities are less but still profit is high it may be for their past reputation and other factors involved with profit.

BRAC Bank Ltd.

CSR

50

0

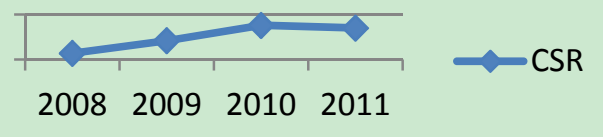

In million

\section{Profit}

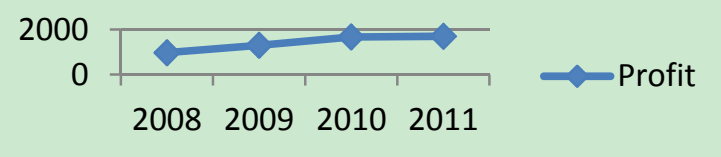

Here we can see that from 2008 to 2010 CSR is rising and profit is also rising. When in 2011 the CSR is lower than previous year and profit is also lower than the previous years. So, we can see a positive relationship between CSR and profit.

Prime Bank

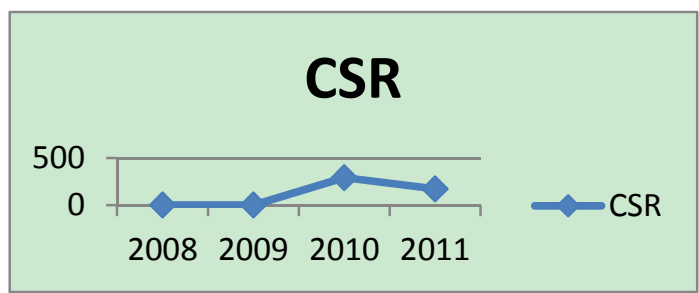

In million

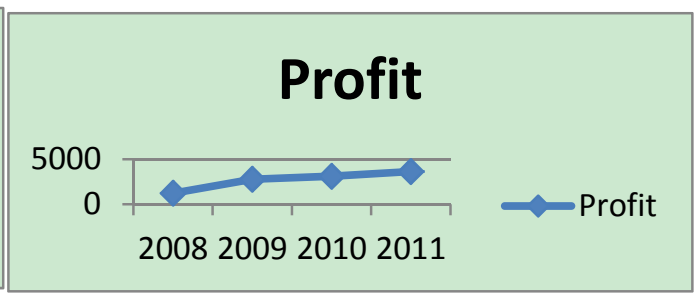


Here in terms of prime bank when in 2008 there were no CSR activities by the bank so we can see that the profit was also lower. In 2010 CSR activities jumped as did the profit also. But in 2011 CSR activities are less but still profit is high it may be for their past reputation and other factors involved with profit.

DBBL

In million

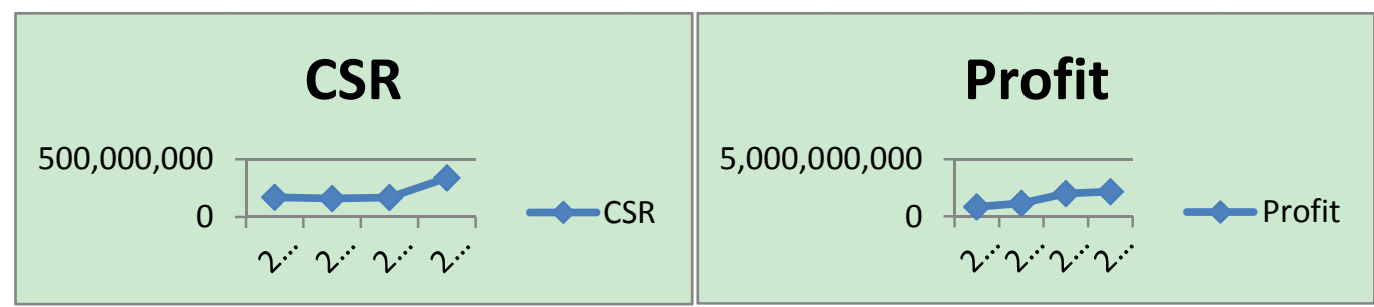

Here from the graph we can see that from 2008 to 2010 CSR activities were lower and in 2011 it jumped and became almost double in a year. We can relate the CSR activities with profit that it will increased along with CSR.

\section{CSR Expenditure- comparison among SCB, PCB, FCB and IB}

\begin{tabular}{llll}
\hline \multicolumn{3}{l}{ Amount in million } & \\
\hline $\begin{array}{l}\text { CSR } \\
\text { expenditure: }\end{array}$ & 2009 & 2010 & 2011 \\
\hline HSBC & 16 & 47 & 32 \\
\hline BRAC & 21 & 38 & 36 \\
\hline EBL & 6 & 31 & 12 \\
\hline Sonali & 0 & 6 & 18 \\
\hline IBBL & 116 & 233 & 411 \\
\hline
\end{tabular}

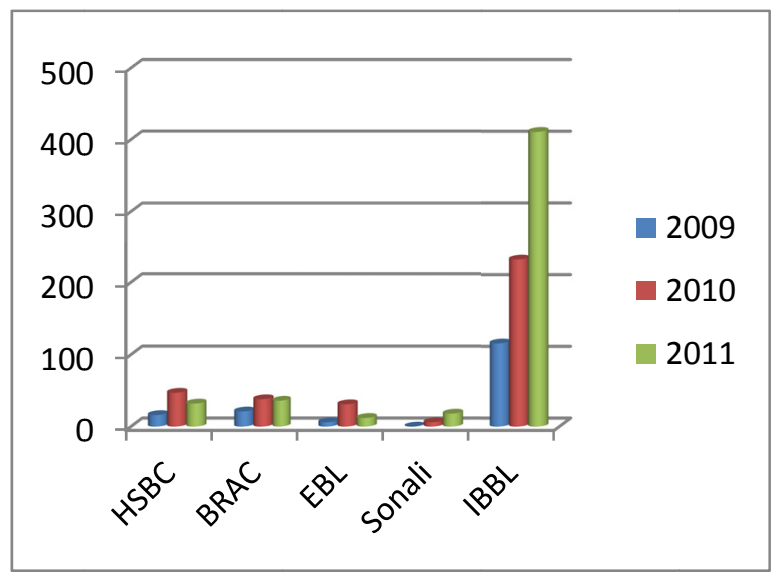

CSR is a unique tool to build a positive image of the bank in customers' mind. It helps a bank to demonstrate that it is indeed a customer oriented bank and not only a profit seeking bank. The above graph shows that IBBL's performance is the best from this aspect among the selected banks. It shows a consistent rise in expenditure in this sector over time. Sonali bank although has the lowest amount of expenditure shows consistent rise. HSBC, BRAC and EBL all 3 have expenditure that increase in 2010 and decrease in 2011. Among these 3 banks BRAC bank's expenditure is the highest.

It is generally held that corporate social responsibility (CSR) could increase company profits and thus most large companies are actively engaged in it. But few executives and managers are aware of the research on this important subject. And as we review here, the research does show that it may improve profits. However, linking profit growth to abstract variables that are frequently difficult to define is challenging task. Most executives believe that CSR can improve profits. They understand that CSR can promote respect for their company in the marketplace which can result in higher sales, enhance employee loyalty and attract better personnel to the firm. Also, CSR activities focusing on sustainability issues may lower costs and improve efficiencies as well.

\section{Conclusion and Recommendation}

Banking sector is one of the flourishing sectors in Bangladesh. In our total GDP service sector has 52.76\% contribution in the fiscal year 2008-2009(Bangladesh Economic Review, 2008-2009). Service sector has the largest percentage of contribution in GDP. Banks are the part of this service sector. So, the social development of the country is vastly depending on banking sector of Bangladesh. So, the social and economic development of Bangladesh can be ensuring 
by the appropriate CSR practice by the banks. But there low general awareness of CSR among banks in Bangladesh. CSR activities are involved in giving donation to charity to local communities and abiding local law and regulation in areas of labor and environmental protection. But CSR means more than that. CSR is a contribution of the company to better society and cleaner environment. But in case of our banks CSR is an emerging stage of development .For banks of Bangladesh Corporate Social Responsibility is not mandatory rather than it is a the part of financial statement that is shown in annual report. CSR is a contribution of the company for its social investment for the sustainable development of the company's level. In the following ways CSR practices among the banks can be improved:

- Bangladesh bank should make it mandatory for all the banks give specific information about CSR with amount and areas and activities are so give them a clear view of CSR. Make a clear view about what types of activities included in CSR practices. Interestingly a few banks use some information like milad, annual picnic, concert, branch opening activities is in their CSR activities.

- Government should encourage commercial banks use their profit portion for CSR activities. Make the banks convince that CSR activities will increase their profit day by day.

- The law and regulatory body of our country should create more uniform law and legislation regarding CSR practice in banking sector.

- Government should encourage banks CSR practices by giving tax rebate. This will encourage banks to do more CSR and which will gradually developed society.

\section{References}

Alex, D., \& John, D. (1988). Corporate Social Reporting in Irish Financial Institutions. The TQM Magazine, 16(6), 385-395. Retrieved from http://www.emeraldinsight.com/doi/abs/10.1108/09544780410563301

Asongu, J.J. (2007). Innovation as Argument for CSR. Journal of Business and Public Policy, 1(3).

Corporate Social Responsibility (CSR) - the societal responsibility of companies. Retrieved from $\mathrm{http} / / /$ en.reset.org/knowledge/corporate-social-responsibility-csr- $\% \mathrm{E} 2 \% 80 \% 93$-societal-responsibility-compani es

Corporate Social Responsibility, World Business Council for Sustainable Development (WBCSD). (2001). Retrieved from http://www.wbcsd.org/work-program/business-role/previous-work/corporate-social-responsibility.aspx

Dima, J., \& Rmez, M. (2007, May). Coporate and Social Responsibility (CSR): Theory and Practice in a Developing Country Context. Journal of Business Ethics, 72(3), 243-262. Retrieved from http://link.springer.com/article/10.1007/s10551-006-9168-4

Keeler, D. (2003). Shaping Up. Global Finance Magazine. Retrieved from http://isites.harvard.edu/fs/docs/icb.topic747719.files/Supplemental\%20Reading\%20Folder/Innovation.pdf

Konrad, A. (2006). "CSR": ZurVerantwortung von Unternehmen, in derStandard.at. Retrieved from http://derstandard.at/2666221/CSR-Zur-Verantwortung-von-Unternehmen

Misser, S. (2006). The corporate responsibility report. Pricewaterhousecoopers, 5, 01-20. Retrieved from http://www.pwc.com/en_GX/gx/sustainability/assets/crreport_vol5.pdf

Moment, R. (2004). The 7 Principle of Business Integrity. Retrieved from http://www.webpronews.com/the-principles-of-business-integrity-2004-07

Paine, L.S. (2003). Value Shift: Why Companies Must Merge Social and Financial Imperatives to Achieve Superior Performance. New York: McGraw-Hill.

Richard, E.S. (2011). Defining Corporate Social Responsibility: A Systems Approach for Socially Responsible Capitalism, University of Pennsylvania Scholarly Commons, 7-1. Retrieved from http://repository.upenn.edu/od_theses_mp/9

Sharma, Y. (2013). Role of corporate social responsibility in organization. IOSR Journal of Business and Management, 13(4), 01-08. Retrieved from http://iosrjournals.org/iosr-jbm/papers/Vol13-issue4/A01340108.pdf

Webley, S., \& More, E. (2001). The Institute of Business Ethics, 24 Greencoat Place, London SW1P 1B, 06-10. Retrieved from http://www.ibe.org.uk/userfiles/publications_leaflet_2011_print_final.pdf 